\title{
Do the Characteristics of Internal Audits and Compliance Functions Affect Sharia Compliance?
}

\author{
Laili Latifah Puspitasari $^{1}$, Wuri Handayani ${ }^{2 *}$ \\ ${ }^{1}$ Department of Center for Religious and Cross-cultural Studies Interest of Islamic Economic Studies, \\ Graduate School of Universitas Gadjah Mada, Yogyakarta, 55281, Indonesia. \\ 2 Department of Accounting, Faculty of Economics and Business, Universitas Gadjah Mada, \\ Yogyakarta, 55281, Indonesia.
}

\begin{tabular}{|c|c|}
\hline ABSTRACT & ARTICLE INFO \\
\hline $\begin{array}{l}\text { Introduction: This study aims to explore the relationship between the } \\
\text { characteristics of an internal audit (IA) and a compliance function (CF) } \\
\text { toward sharia compliance. Background Problems: The Sharia } \\
\text { Supervisory Board (SSB), which is supposed to guarantee sharia } \\
\text { compliance in Islamic banking, does not function properly. } \\
\text { Consequently, the SSB delegates this supervision to the banks' } \\
\text { employees, so the compliance function and internal audit become } \\
\text { common practices used to address any issues. Novelty: The majority of } \\
\text { previous studies have examined the role/characteristics of the SSB in } \\
\text { sharia compliance. On the other hand, few studies have examined the } \\
\text { role/characteristics of IA and CF in sharia compliance. Therefore, this } \\
\text { study was conducted to examine the characteristics of IA and CF toward } \\
\text { sharia compliance. Research Method: The study utilized the seven } \\
\text { Islamic banks in Indonesia which published their annual reports for the } \\
\text { period from } 2011 \text { to } 2018 \text { as its research sample. The analysis technique } \\
\text { used in this study is a multiple regression analysis. Results: The results } \\
\text { indicated that IA and CF competencies had a positive effect toward the } \\
\text { sharia compliance of Islamic banks in Indonesia. Conclusion: It is } \\
\text { necessary to enhance the competencies of IA and CF staff through } \\
\text { improving their professional qualifications, such as through education } \\
\text { programs, certification and relevant training on the scope of sharia } \\
\text { supervision. Such actions need to be done to support IA and CF staff in } \\
\text { performing the comprehensive supervision of sharia compliance. }\end{array}$ & $\begin{array}{l}\text { Keywords: } \\
\text { internal audit, compliance } \\
\text { function, sharia } \\
\text { compliance, sharia } \\
\text { supervision, sharia } \\
\text { governance }\end{array}$ \\
\hline
\end{tabular}

\footnotetext{
* Corresponding Author at Department of Accounting, the Faculty of Economics and Business, Universitas Gadjah Mada, Jalan Socio Humaniora No. 1, Yogyakarta 55182, Indonesia.
} 


\section{INTRODUCTION}

Compliance with the sharia principles found in the halal products and services offered by Islamic banks becomes one of the pivotal reasons for Muslims to prefer Islamic banks (Prakosa \& Zuchri, 2011). As a result, the pursuit of sharia compliance is mandatory for Islamic banks to sustain the credibility and legality of halal products and services, along with securing public trust in the Islamic banking system (Haridan, Hassan, \& Karbhari, 2018). To strive for sharia compliance, each Islamic bank has a Sharia Supervisory Board (SSB) to monitor and control any mechanism minimizing activities that are not in accordance with sharia principles (Zainuldin, Lui, \& Yii, 2018).

However, some previous studies have demonstrated that the function of the SSB, as a guarantor institution for sharia compliance in Islamic banking, does not work properly (Hasan, 2014). One of the causes is due to the lack of sharia supervision and an inability to allocate adequate time for members of the SSB to conduct sharia supervision properly, as a result of the other activities undertaken by members of the SSB (CISI, 2010). Consequently, sharia supervision is delegated by the SSB to internal bank employees, such as those who undertake the compliance function (CF) or internal audit (IA). This has now become a common practice to address the issue (Nugraheni, 2012).

In principle, the existence of CF and IA is intended as a support system to the SSB in performing its sharia compliance supervision (PBI No.11/33/PBI/2009 concerning Good Corporate Governance (GCG) Implementation for Sharia Commercial Banks (BUS) and Sharia Business Units (UUS)). Ideally, the SSB plays a major role in sharia's governance, especially in its supervision process. However, the practice of delegating sharia supervision to IA and CF staff suggests that the SSB is very dependent on both functions to implement sharia supervision (Haridan et al., 2018). This phenomenon requires Islamic banks to improve the characteristics of their IA and CF teams in an effort to ensure the purpose of Islamic banks, which is to convey the legality of the halal products and services offered by Islamic banks (Khalid, Haron, \& Masron, 2017).

Considering the fact that sharia compliance's supervision has become the responsibility of IA and CF staff, the effectiveness of the roles of both functions as sharia governance organs, especially for the supervision of sharia compliance, has become an issue that needs further investigation. Moreover, previous studies into sharia supervision tested the role/characteristics of the SSB for sharia governance, but little research has been done into the characteristics of IA and $\mathrm{CF}$ for sharia governance and sharia compliance. Both IA and CF are also included as sharia governance organs involved in the sharia supervision process. The majority of studies testing the SSB's performance were conducted by Haridan et al., (2018), Violita \& Handarbeni (2017), Noordin \& Kassim (2016), Rahman \& Bukair (2013). Thus, further research into the role of IA and CF in sharia compliance is needed.

The research that examined the characteristics of IA was mostly conducted in public sector companies, such as in the studies by Alzeban (2018), Alzeban \& Gwilliam (2014), and Ahmad, Othman, Othman, \& Jusoff (2009). In general, some of these studies examined the role or characteristics of IA for its performance; thus, it is necessary to examine the effect of IA characteristics toward sharia compliance as a key to actualize good governance.

Furthermore, little research has examined the characteristics of IA in sharia financial institutions, although Khalid et al., (2017) tested 
the characteristics and performance of IA in Islamic financial institutions in Bahrain. Previous research related to $\mathrm{CF}$ has included a study by Violita \& Handarbeni (2017), which pointed out the sharia compliance monitoring procedures in Islamic banks, and described the relationship between SSB and CF and IA in implementing sharia compliance monitoring.

Based on this background, this study aims to fill the gap left by the previous studies by testing other sharia governance organs such as IA and CF for their ability to monitor sharia compliance. Through this research, testing will be performed to find out the characteristics of IA and $\mathrm{CF}$ including their: competencies, work programs, and number of members for ensuring sharia compliance in Sharia Commercial Banks (BUS) in Indonesia.

\section{LITERATURE REVIEW}

\section{Corporate Governance from the Islamic Perspective}

Corporate governance has been a debatable topic after the collapse of giant companies such as Enron, Worldcom, and Arthur Andersen due to fraud in their accounting practices and governance deviations, which had a detrimental effect on stock prices, the capital markets, and investor confidence, along with them losing a large amount of their investment. The effect of these companies' scandals resulted in investors demanding governance mechanisms that could increase the transparency and accountability of corporate executives (Elad, Wong, \& Bongbee, 2018).

The concept of corporate governance, from an Islamic perspective, is not much different from corporate governance in the conventional perspective, since both include a system in which companies are directed and controlled to achieve their company objectives by protecting all the interests and rights of their stakeholders (Hasan, 2009).

The principle of corporate governance, from an Islamic perspective, is based on the epistemological aspect of monotheism. Tawhid refers to the recognition of God's right and the responsibilities of all stakeholders. Responsibility to God is interpreted in the concept of accountability, including companies, which are the representatives of God and are accountable for their own actions. Therefore, the context of corporate governance, from the Islamic perspective, goes beyond the relationship among the shareholders, boards of directors, management, and stakeholders, to how one can maintain the relationship with God (ISRA, 2015).

\section{Corporate Governance Mechanisms in Islamic Banking in Indonesia}

Islamic banks are established as ethical financial institutions that have a fundamental obligation to be fully compliant with sharia principles in the products and services they offer. Sharia law prohibits Islamic banks from being involved in transactions containing usury (interest), gharar (speculative trading), and maysir (gambling), as well as activities that lead to exploitation. Unlike conventional banks, sharia compliance is a unique characteristic of Islamic banks, because it is able to build the stakeholders' trust in the legality of the halal products and services offered by Islamic banks (Haridan et al., 2018).

For this reason, the majority of Islamic banks have a Sharia Supervisory Board (SSB) which is supposed to hold the highest responsibility for ensuring sharia compliance. To support the sharia supervisory process implemented by the SSB, through Bank Indonesia Regulation (PBI) No.11/33/PBI/2009 concerning the Implementation of Good Corporate Governance (GCG) for Islamic/Sharia Commercial Banks (BUS) and 
Sharia Business Units (UUS), sharia banks are required to form their own internal audit (IA) and compliance function (CF) teams. Both functions are tasked with providing accurate and relevant data and information related to compliance with sharia principles to the SSB.

Coordination between the SSB and IA and $\mathrm{CF}$ teams in the sharia supervision process is mandated in Bank Indonesia (SEBI) Regulation No.12/13/DPbS/2010 concerning GCG Implementation for BUS and UUS, including the implementation of sharia supervision to determine the quality of compliance with sharia principles. Therefore, it is concluded that the roles of IA and CF intersect each other for implementing sharia supervision.

Based on PBI No. 13/2/PBI/2011 concerning the Implementation of Compliance Function of Commercial Banks, it is stated that the duty of the $\mathrm{CF}$ is to conduct preventive (ex-ante) sharia supervision, to ensure that policies, provisions, systems and procedures, as well as business activities, are in accordance with Bank Indonesia regulations, the applicable laws, including those covering the sharia principles. Furthermore, IA is in charge of curative (ex-post) sharia supervision, including the implementation of the audit process after performing a transaction.

Previous research has identified how to measure the effectiveness of the IA's and CF's roles (Alzeban, 2018; Khalid et al., 2017; Alzeban \& Gwilliam, 2014) as organs of governance. Some characteristics which are commonly utilized include competence, work programs, and the number of members.

\section{Sharia Compliance}

Sharia compliance in Islamic banks means that the operational activities and products offered by Islamic banks do not conflict with sharia principles (Rahman \& Bukair, 2013). Sharia compliance thus reflects the prinsciple of halal transactions in Islamic banks, discarding the elements of usury, gharar, maysir, and zalim. For Muslims, sharia compliance in their economic activities satisfies a spiritual need by protecting their property from prohibited deeds (Zainuldin et al., 2018).

As a result, Islamic banks are obliged to ensure that their products and operations are compliant with sharia principles, because stakeholders have the right to be assured that the products and operations of Islamic banks already meet sharia principles (Bukair \& Rahman, 2015). Moreover, based on the Islamic perspective, the main purpose of reporting in Islamic banks is to demonstrate that their transactions comply with sharia principles and rules (Bukair \& Rahman, 2015).

Ibrahim, Wirman, Alrazi, Nor, \& Pramono (2004) have tried to evaluate sharia compliance in Islamic banks, including the Islamicity Disclosure and Performance Index. The first element is utilized to assess Islamic banks in their disclosure of information to facilitate stakeholders in evaluating the sharia compliance, governance, and social activities of Islamic banks. The second element emphasizes the performance of Islamic banks' products.

The Sharia Compliance Indicator (SCI) is a component of the Islamicity Disclosure Index to assess the quality of sharia compliance by Islamic banks in their annual reports. Therefore, this study employs SCI as a measure of sharia compliance, to determine the level of sharia compliance of the Islamic banks. SCI is divided into three main dimensions, including: information about the SSB, basic information about Islamic banks, and financial statements. 


\section{DEVELOPMENT OF HYPOTHESES}

\section{Internal Audit and Compliance Function Competencies}

Alzeban \& Gwilliam (2014) divide competency into four dimensions, namely; educational qualifications, professional qualifications, experience in related fields, and sustainable development. Educational qualifications are interpreted by the degrees obtained through formal education, while professional qualifications are interpreted by the various certifications obtained through non-formal education related to certain fields (Alzeban \& Gwilliam, 2014; Ginena \& Hamid, 2015). Experience in a related field is interpreted by the time taken to pursue, undergo, or occupy a position in a particular field, while sustainable development is interpreted through ongoing training related to the related field (Ginena \& Hamid, 2015).

Ideally, IA members have relevant professional certifications such as those awarded to Certified Sharia Advisers and Auditors (CSAA) and Certified Islamic Professional Accountants (CIPA) issued by AAOIFI and Certified Internal Auditors (CIA) issued by the Institute of Internal Auditors' (IIA). Furthermore, CF members should ideally have professional certification related to Islamic banking, and risk management certification. Considering the CF's task is to strive for Islamic banks to comply with sharia principles and BI regulations, the CF's staff are required to have a sound understanding of managing the risks that may be experienced by Islamic banks. An adequate understanding of the operations of Islamic banks and risk management is believed to be sufficient to support a CF team in carrying out its duties.

Just like the members of the SSB, IA and CF teams are ideally required to have sufficient knowledge in the field of fiqh muamalat (Grais \& Pellegrini, 2006). Yahya \& Mahzan (2012) pointed out that fiqh muamalat would increase the equality in issues related to sharia noncompliance. As a result, the potential risk of sharia non-compliance can be minimized. Furthermore, integral knowledge between fiqh muamalat/Islamic law and financial/accounting/ auditing is supported by ongoing training and relevant experience that will greatly support the effectiveness of sharia supervision (Ginena \& Hamid, 2015). In addition, it was stated by Ginena \& Hamid (2015) that greater experience in the relevant fields will allow IA and CF personnel to comprehensively supervise the various aspects of sharia compliance, as they have mastered those fields. Furthermore, Ginena $\&$ Hamid stated that the more experience IA and CF have in the relevant fields, supported by integral knowledge, this will make it easier for them to work more efficiently.

In addition, Ali (2007) in Khalid et al., (2017) postulated that the lack of members who have competence in aspects of knowledge, experience and training will have a negative impact on the performance of a governance organ. This finding is in line with the study by Alzeban \& Gwilliam (2014), who stated that the lack of competence in IAs was the main cause of misunderstandings during auditing. Based on this explanation, the first hypothesis is formulated as follows:

H1: IA and CF team members' competencies have an influence on sharia compliance.

\section{Internal Audit and Compliance Function Work Programs}

CF's scope of work is defined by Bank Indonesia Regulation (PBI) No.13/2/PBI/2011 concerning Implementation of Compliance Function of Commercial Banks, and covers preventive (ex-ante) supervision, by ensuring that all policies, provisions, systems, procedures, 
and business activities are in accordance with Bank Indonesia regulations, the applicable laws and regulations, and sharia principles. On the other hand, IA's scope of work includes curative (ex-post) supervision and conducting audits after transactions take place.

In the scope of sharia supervision, IA and CF function as support systems for the SSB, and are responsible for providing information regarding aspects of sharia compliance. Furthermore, CF is responsible for the procedures and mechanisms to implement sharia supervision until reports on SSB's supervision activities are prepared; while IA reports on branch audit findings including aspects of sharia compliance (Bank Syariah Mandiri, 2017).

To supervise sharia compliance, IA and CF staff design work programs based on the objectives of the implementation. Khalid et al., (2017) stated that these IA and CF work programs, if they are effectively designed and implemented, would lead to comprehensive sharia compliance monitoring. Based on this explanation, the second hypothesis is formulated as follows:

H2: IA and CF staff work programs have an influence on sharia compliance.

\section{Number of Internal Audit and Compliance Function members}

Haji and Ghazali (2013), on Noordin \& Kassim (2016), indicated that a greater number of members in a governance body should provide more collective knowledge and skills. Moreover, the diversity of knowledge and skills and experience among such members is believed to facilitate the supervision process of sharia compliance (Rahman \& Bukair, 2013). Through this statement, it is apparent that a greater number of members should lead to more effective sharia supervision. A further argument was stated by Ali et al. (2007) in Ahmad et al., (2009), that the lack of members in governance organs teams such as those for IA and CF, is one of the causes of ineffectiveness and poor performance by these functions, which will lead to less optimal supervision of sharia compliance. Based on this explanation, the third hypothesis is formulated as follows:

H3: The number of IA and CF team members has an influence on sharia compliance.

Based on the explanation above, this study aims to examine the influence of the characteristics of both IA and CF, which are proxied for the competencies, work programs, and number of members for ensuring sharia compliance by the BUS in Indonesia. Based on the research objectives, the following is the research framework:

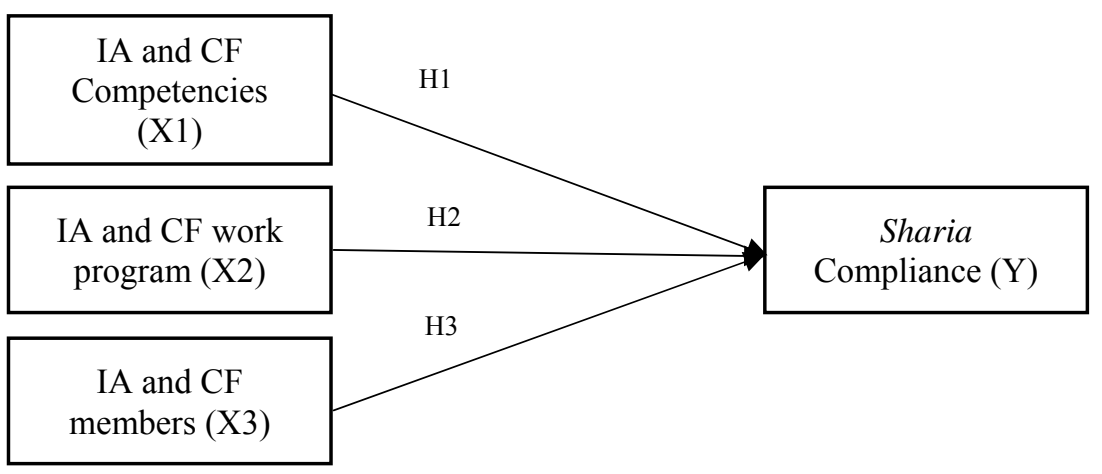

Figure 1. Research Framework 


\section{METHOD, DATA, AND ANALYSIS}

This study was conducted to examine the effect of the characteristics of IA and CF staff on sharia compliance by the BUS in Indonesia from 2011 to 2018. The Islamic banking system in Indonesia consists of sharia commercial banks (BUS), sharia business units (UUS), and sharia rural banks (BPRS), yet this study only focuses on BUS due to the availability of information related to the necessary research data, which is more plentiful than that available for the UUS and BPRS.

The population of the study involves all the BUS in Indonesia that published their annual reports during the period from 2011 to 2018, which number 11 BUS. This study employs information on Islamic banks taken from their annual reports, downloaded from the official BUS websites to obtain information about sharia compliance and the characteristics of the IA and $\mathrm{CF}$ teams as our research data. Based on the identification of sharia compliance information as well as the characteristics of the IA and CF teams, only seven out of the 11 BUS provided the required information related to our research data.

The observation period was from 2011 to 2018, to provide sufficient time for BUS to comply with PBI No.11/33/PBI/2009 concerning GCG Implementation for BUS and UUS. This was the start of the obligation for BUS and UUS to form IA and CF functions for their governance. The regulation came into force on January 1, 2010; thus, 2011 was selected to allow this study to obtain significant results on IA and CF functions in the disclosures of the Islamic banks. The report in 2018 was the most recent annual report available during this research.

Information about sharia compliance in annual reports was obtained from the company profile section, corporate governance, financial statements, and notes to financial statements. Meanwhile, the information about the characteristics of the IA and CF staff in the annual report was obtained from the company profile and corporate governance section. In addition to the annual report, supporting data sources such as LinkedIn and Bloomberg were also utilized to obtain information about IA and CF members' profiles and backgrounds, if the information was not available in the annual reports.

The annual report becomes the main data source in this study for several reasons. First, the annual report provides the main source of information for stakeholders when making decisions (Rahman \& Bukair, 2013). Second, annual reports are recognized as sources of information with a high level of credibility (Noordin \& Kassim, 2016). Third, annual reports are easily accessible for research purposes (Noordin \& Kassim, 2016). The following is a list of the BUS in this study:

Table 1. List of Sharia Commercial Banks

\begin{tabular}{cll}
\hline No & Name of BUS & Abbreviation \\
\hline $\mathbf{1}$ & Bank Central Asia Syariah & BCAS \\
$\mathbf{2}$ & Bank Negara Indonesia Syariah & BNIS \\
$\mathbf{3}$ & Bank Rakyat Indonesia Syariah & BRIS \\
$\mathbf{4}$ & Bank Syariah Mandiri & BSM \\
$\mathbf{5}$ & Bank Syariah Bukopin & BSB \\
$\mathbf{6}$ & Bank Mega Syariah & BMS \\
$\mathbf{7}$ & Bank Muamalat Indonesia & BMI \\
\hline Source: Processed secondary data (2019) &
\end{tabular}




\section{Variable Measurenment}

\section{Dependent Variable}

The dependent variable in this study is sharia compliance, measured by applying the SCI as initiated by Ibrahim et al., (2004). The SCI is an instrument to assess the Islamic banks' disclosure of information to assist stakeholders in evaluating the banks' sharia compliance. For this reason, SCI is utilized to examine sharia compliance based on the disclosures in the Islamic banks' annual reports. SCI is divided into three main themes, including the SSB, basic Islamic banking information, and financial statements as described in the following:

a. Sharia Supervisory Board (SSB)

The SSB is the responsible appointed body for ensuring that the operations of Islamic banks do not conflict with sharia principles. Due to the importance of the SSB's role, its existence is obligatory for Islamic banks (Ibrahim et al., 2004). Therefore, Islamic banks must disclose their SSB members' appointments, names, educational backgrounds, and SSB experience.

b. Basic Information

Islamic banks have different objectives than conventional banks; Ibrahim et al., (2004) stated that they must provide clear information about their goals, vision and mission and main activities in their annual reports.

c. Financial Report

The differences in the objectives of Islamic banks and conventional banks are in the provision of additional information. Information is required to assist the concerned parties to assess Islamic banks' compliance with sharia principles. Based on these assumptions, Ibrahim et al., (2004) initiated evaluated the nine items that Islamic banks must disclose in their annual reports, which can be utilized to assess the level of implementation of sharia principles in Islamic bank operations, which are:

1. Identification of halal investments.

2. Identification of non-halal investments.

3. Identification of halal income.

4. Identification of non-halal income.

5. Provision of a statement on the source and use of zakat and sadaqah funds.

6. Provision of a statement on the sources and uses of qardh funds.

7. Identification of sources of income.

- Excluding depositors' income.

- Excluding income from murabahah financing.

8. Application of current value when possible.

9. Value added statement.

The SCI is calculated based on the disclosed information in each bank's annual report. If information is revealed, it will be given a value of 1 , and 0 if not revealed. The formula for calculating SCI follows:

$$
S C I=\frac{\sum_{i=1}^{n=j} X i j}{n j}
$$

Information:

$\mathrm{X}=1$ if revealed, 0 if not revealed

$\mathrm{n}=$ total items

After the scoring is accomplished, the percentage value of sharia compliance is obtained to classify Islamic banks based on their level of compliance, as illustrated in Table 2.

Table 2. Sharia Compliance Indicator

\begin{tabular}{cc}
\hline Value & Rank \\
\hline $\mathbf{0}-\mathbf{2 5} \%$ & Lowest \\
$\mathbf{2 6 - 5 5 \%}$ & Low \\
$\mathbf{5 6 - 8 0} \%$ & Middle \\
$\mathbf{8 1 - 9 0 \%}$ & High \\
$\mathbf{9 1 - 1 0 0 \%}$ & Highest \\
\hline
\end{tabular}

Source: Murtiyani (2008) in Fahlevi \& Randa (2017) 


\section{Independent Variable}

The independent variables in this study are the characteristics of the IA and CF bank staff which consist of: (i) IA and CF competencies; (ii) IA and CF work programs; (iii) the number of IA and $\mathrm{CF}$ members. These characteristics have been commonly utilized in previous studies (Alzeban, 2018; Khalid et al., 2017; Alzeban \& Gwilliam, 2014) to assess the effectiveness of a governance organ's performance.

\section{a. IA and CF Competencies}

The first independent variable is IA and CF competencies; which is the ability of individuals to appropriately carry out their duties and responsibilities (Shamsuddin, Manijegar, \& Kanagambikai a/p Kirupanangtan, 2014). Alzeban \& Gwilliam (2014) divide competency into four dimensions, including: educational qualifications, professional qualifications, work experience in related fields, and sustainable development. The measurement of the competency variables is calculated based on the percentage of the values of the four items of competence, which are as follows:

1. Educational qualifications, a degree through formal education, with a score of 2 if a financial/accounting/audit and sharia education degree; 1 if a financial/ accounting/audit or sharia education degree, and 0 if the education degree is other than finance/accounting/auditing or not sharia based.

2. Professional qualifications, obtained through non-formal education, with a score of 2 if possessing QIA, CIPA, CSAA, CPA for IA and BSMR certificates, or Islamic banking training certification for CF; 1 if holding one of QIA, CIPA, CSAA, CPA for IA and BSMR certificates, or sharia banking training certification for $\mathrm{CF}$; and 0 if no certificate is related to the field of IA and $\mathrm{CF}$.

3. Work experience in the related field, determined by the number of years that have been passed with a score of 2 if having experience in related fields for $>$ 12 years; 1 if having experience in the related fields for 6 to 11 years; 0 if the experience in the related field is $<5$ years.

4. Continuous development, training undertaken after becoming an employee in a related field, with a score of 2 if having participated in $>12 \times$ training sessions related to IA and CF for a year; 1 if taking 6 to $11 \mathrm{x}$ training sessions related to IA and CF for a year; and 0 if undertaking $<5$ training sessions related to IA and CF for a year.

The total value of the four competency items (educational qualifications, professional qualifications, experience in related fields, and sustainable development) is then compared with the ideal value for each item. The ideal value is assumed if all four items in the competency obtain a score of 2 from each item.

$$
\text { Competence }=\frac{\sum \begin{array}{c}
\text { total value of } \\
\text { disclosure items }
\end{array}}{\sum \text { ideal value }} \times 100
$$

\section{b. IA and CF Work Program}

The second independent variable includes the IA and CF work program, interpreted by Khalid et al., (2017) as a work plan arrangement that is made as a guide or target for carrying out responsibilities. The measurement of a work program's variables is calculated through a comparison of the actual work program's quantity with the previously planned work program, presented by sharia banks in their 
annual report. The following is the formula for calculating the work program variables:

$$
\text { Work Program }=\frac{\sum_{\text {work program }}^{\text {realization of }}}{\sum_{\text {work program }}^{\text {plan of }}} \times 100
$$

c. Number of IA and CF Members

The last independent variable includes the number of IA and CF members, measured by the number of members in the bank's IA and CF departments. The following is the formula for calculating the variable number of members:

$$
\begin{gathered}
\text { Number of } \\
\text { Members }
\end{gathered}=\sum \text { Number of Members }
$$

Furthermore, the operational definitions and measurements of the variables in this study include: sharia compliance, competence, work program, and number of members which are summarized in Table 3 below.

\section{Multiple Linear Regressions}

This study utilizes a multiple linear regression to examine the effect of IA and CF characteristics on sharia compliance. The following is the regression equation model in this study:

$$
\mathrm{Yit}=\alpha+\beta 1 \mathrm{X} 1 \mathrm{it}+\beta 2 \mathrm{X} 2 \mathrm{it}+\beta 3 \mathrm{X} 3 \mathrm{it}+\varepsilon \mathrm{it}
$$

Note:

$$
\begin{array}{ll}
\mathrm{Y} & =\text { Sharia compliance } \\
\alpha & =\text { Constant } \\
\beta 1-\beta 3 & =\text { Regression coefficients } \\
\mathrm{X} 1 & =\text { IA and CF competencies } \\
\mathrm{X} 2 & =\text { IA and CF work programs } \\
\mathrm{X} 3 & =\text { Number of members of IA and CF } \\
\varepsilon & =\text { Variables outside the model } \\
\mathrm{i} & =\text { The i. entity } \\
\mathrm{t} & =\text { The t-period }
\end{array}
$$

\section{RESULT AND DISCUSSION}

\section{Descriptive Statistics}

Table 4 presents the results of the descriptive statistical analysis that provides an overview of the characteristics of sharia compliance data, as well as the characteristics of the IA and CF teams in the BUS in Indonesia, for the period from 2011 to 2018. In Table 4, it is apparent that the average value of sharia compliance $(\mathrm{Y})$ is $80 \%$ of all indicators in the SCI. These findings are consistent with research conducted by Fahlevi \& Randa (2017) which demonstrated an average value for sharia compliance of $80 \%$ in the BUS in Indonesia for the period from 2011 to 2013 .

Table 3. Variable Operational Definitions

\begin{tabular}{ll}
\hline \multicolumn{1}{c}{ Variable } & \multicolumn{1}{c}{ Definition } \\
\hline Sharia compliance & $\begin{array}{l}\text { Sharia compliance is evaluated based on disclosures in the annual report using } \\
\text { the indicator for SCI (Ibrahim et al., 2004). }\end{array}$ \\
IA and CF competence & $\begin{array}{l}\text { IA and CF competencies were evaluated by using four indicators of: academic } \\
\text { qualifications, professional qualifications, relevant experience, and continuous } \\
\text { development (Alzeban \& Gwilliam, 2014). }\end{array}$ \\
IA and CF work program & $\begin{array}{l}\text { IA and CF work programs are evaluated based on the quantity of planned work } \\
\text { and the realization of work program (Khalid et al., 2017). }\end{array}$ \\
$\begin{array}{l}\text { Number of IA and } \\
\text { members }\end{array}$ & \begin{tabular}{l} 
CF $\begin{array}{l}\text { Number of IA and CF members is evaluated based on the number of members } \\
\text { in the relevant departments (Alzeban, 2018). }\end{array}$ \\
\hline
\end{tabular}
\end{tabular}
Source: Processed secondary data (2019) 
Table 4. Descriptive Statistics Test Results

\begin{tabular}{lcccc}
\hline & Y & X1 & X2 & X3 \\
\hline Mean & 80.19071 & 59.26339 & 109.8393 & 47.46429 \\
Maximum & 87.50000 & 93.75000 & 195.0000 & 132.0000 \\
Minimum & 62.50000 & 18.75000 & 87.00000 & 13.00000 \\
Std. Dev. & 6.722875 & 18.11387 & 20.28414 & 32.82181 \\
\hline
\end{tabular}

Source: Processed data (2019)

This finding indicates that sharia compliance, as revealed by the BUS in their annual reports remained unchanged, especially when based on the sharia compliance criteria in the SCI (Murtiyani, 2008 in Fahlevi \& Randa, 2017), in which the average value of $80 \%$ is included in the medium rating (56-80\%). For this reason, it is interpreted that the BUS have not been fully compliant with sharia. Therefore, they are advised to increase their efforts to be fully compliant with sharia, as mandated in PBI No.11/33/PBI/2009 concerning the GCG Implementation for BUS and UUS, so the sharia banking industry can be seen to comply with sharia principles.

\section{Hypothesis testing}

This study utilized a multiple regression analysis to examine the effect of IA and CF team characteristics on sharia compliance. Through a regression analysis test, the results are depicted as follows:

Table 5. Hypothesis Test Results

\begin{tabular}{lcc}
\hline Variables & Coefficient & P-value \\
\hline $\mathrm{C}$ & 61.77446 & 0.0000 \\
Competence (X1) & 0.170816 & 0.0003 \\
Work program (X2) & 0.052366 & 0.1602 \\
Number of members (X3) & 0.053542 & 0.0633 \\
\hline R-squared & 0.341816 \\
F-statistic & 9.001774 \\
Prob (F-statistic) & 0.000067 \\
N & \multicolumn{2}{c}{56} \\
\hline
\end{tabular}

Source: Processed data, 2019.

Table 5 indicates that the $\mathrm{R}^{2}$ value is 0.341816 , clarifying that the proportion of IA and $\mathrm{CF}$ characteristics (competence, work program, and number of members) on sharia compliance is $34.18 \%$. Through hypotheses testing, it is apparent that IA and CF staff competencies have a positive and significant effect at the $1 \%$ level. This finding explains that IA and CF staff competencies are one of the determining factors that influence the BUS' sharia compliance in Indonesia. This finding is consistent with Noordin \& Kassim (2016), demonstrating that strong knowledge in the field of sharia and other professional skills has a positive relationship with the effectiveness of monitoring the disclosure activities of Islamic banks, in relation to their sharia principles.

This finding is in line with Ginena \& Hamid (2015), and points out that a good mixture of academic qualifications, sustainable development, and relevant experience will lead to effective IA and CF team performance; thus, sharia compliance in Islamic banks can be properly monitored. Table 4 indicates that the average value of IA and CF staff competencies is $59 \%$, confirming that the majority of the academic qualifications held by IA and CF members are non-sharia. This finding thus requires the BUS to improve the qualifications held by their IA and CF staff. As stated by Yahya \& Mahzan (2012), the biggest challenge for sharia supervision, when carrying out sharia audits, is the lack of members with competence in sharia (fiqh muamalat) and finance/ accounting/auditing.

On the contrary, through the hypotheses test, it was apparent that IA and CF work programs 
and the number of IA and CF members were found to have no effect on the sharia compliance of the BUS in Indonesia. The findings in this study do not support the research conducted by Khalid et al., (2017) which indicated that work programs have a positive effect on the effectiveness of sharia supervision. The findings in this study, according to Rahman (2008) in Khalid et al., (2017), appear to indicate that sharia supervision in Islamic banks is not currently implemented comprehensively, and fails to cover all the problems with sharia in the financial, social, organizational structure, and management ethics aspects (Khalid et al., 2017; Zainuldin et al., 2018).

Furthermore, as stated by Khalid et al., (2017), the effectiveness of the IA and CF work programs for sharia supervision is very dependent on the SSB, because in principle the two functions are to support the SSB in implementing sharia supervision. However, in carrying out their duties, the two functions do not have any specific guidance from the SSB regarding the supervision of sharia compliance (Baehaqi, 2014). This causes both IA and CF work programs for sharia supervision to not be complied with, so all the aspects of sharia compliance cannot be guaranteed. As a result, even though the number of IA and CF work programs is in line with the number planned, this does not have an effect on the sharia compliance of the BUS in Indonesia.

In line with the IA and CF work programs, the number of IA and CF members was also found to have no effect on the sharia compliance of the BUS in Indonesia. The findings in this study do not support the research of Ahmad et al., (2009) and Noordin \& Kassim (2016) which demonstrated that the number of members with sharia supervisory functions positively influences the effectiveness of the supervision of sharia compliance. The findings of this study, according to Yahya \& Mahzan (2012) appear to be due to the lack of IA and CF members with competence in the field of sharia, and finance/ accounting, having no effect on sharia compliance.

This suggests that the number of IA and CF members will not affect sharia compliance as long as the two functions do not have sufficient numbers of members who have competence in the field of sharia/muamalat fiqh and finance/ accounting/auditing. Furthermore, according to Garas (2012) in Noordin \& Kassim (2016), a greater number of members in a governance organ can lead to various kinds of arguments, which leads to inefficiencies in the decisionmaking process.

\section{CONCLUSION}

The purpose of this study was to examine the effect of the characteristics of IA and CF toward the sharia compliance of the BUS in Indonesia. The characteristics of IA and CF staff in this study are proxied by competence, work program, and the number of members. The results showed that IA and CF members' competency had a positive and significant effect on the sharia compliance of the BUS in Indonesia for the period from 2011 to 2018 . Through this study, it was proven that Islamic banks that have IA and CF staff who have academic qualifications, professional qualifications, relevant experience, and sustainable development will provide better disclosures regarding their aspects of sharia compliance. In contrast, the IA and CF work programs and the number of IA and $\mathrm{CF}$ members were found to have no effect on the sharia compliance of the BUS in Indonesia.

The findings in this study provide some implications for further improvements in Islamic banking in Indonesia. This study supports the previous studies which demonstrated that the characteristics of IA and CF staff that are 
proxied to competencies, positively and significantly influence the effectiveness of sharia supervision, and ensure sharia compliance by the BUS in Indonesia.

Therefore, this study is beneficially applicable as a reference for Islamic banks in an effort to improve the competence of their IA and $\mathrm{CF}$ teams. In addition, it was found that the average value of IA and CF competencies was still 59\%, indicating that there is still a need for improvement, especially in the aspects of professional qualifications and sustainable development. Based on the research data, the academic qualifications of the majority of IA and CF members are non-sharia. For this reason, it is necessary to increase the qualifications related to sharia law and fiqh muamalat to support the IA and $\mathrm{CF}$ functions in supervising sharia compliance. Increasing their professional qualifications can be conducted through continuous education programs, and the participation of IA and $\mathrm{CF}$ members in certification and training relevant to their supervisory function of sharia.

Relating to the regulations concerning sharia governance organs, IA and CF (as stated in PBI No. 11/33/PBI/2009 regarding GCG Implementation for BUS and UUS, in SEBI No.12/13/DPbS/2010 concerning GCG Implementation for BUS and UUS, and in PBI No.13/2/PBI/2011 concerning Implementation of Compliance Function of Commercial Banks) are expected to be more specific about the criteria that Islamic banks must meet in forming their IA and CF departments. In some of these regulations, it is not explained in detail about the criteria for competency requirements that must be owned by IA and CF members and there are no standard provisions regarding the number of IA and CF members that must be on the staff of sharia banks.

This study has several limitations that can be utilized as opportunities for further research.
First, based on previous empirical studies, IA and $\mathrm{CF}$ work programs become the determinant variables of performance effectiveness leading to comprehensive sharia supervision. However, IA and $\mathrm{CF}$ work programs, when measured by their quantity values (comparison of the number of planned and realized work programs), were found to have no effect on sharia compliance. This phenomenon was probably due to the fact that this research still did not apply IA and CF work program measurements (based on quality, for example the effectiveness of work programs or the usefulness of work programs). Therefore, further research is advised to utilize qualitybased measurements for the work program variables, not on the quantity of comparison of planned work programs with actualized work programs.

Second, the measurement of sharia compliance in this study is only based on the disclosure of the BUS' annual reports, further research is advised to utilize more comprehensive measurements of sharia compliance's quality, such as by employing sharia financial ratios (Fahlevi \& Randa, 2017) and sharia compliance on the contractual terms and conditions of transactions (Segarawasesa, 2018).

\section{REFERENCE}

Ahmad, N., Othman, R., Othman, R., \& Jusoff, K. (2009). The effectiveness of internal audit in Malaysian public sector. Journal of Modern Accounting and Auditing, 5(9), 53.

Alzeban, A. (2018). The association between internal audit department characteristics and IFRS compliance. Asian Review of Accounting.

Alzeban, A., \& Gwilliam, D. (2014). Factors affecting the internal audit effectiveness: A survey of the Saudi public sector. Journal of International Accounting, Auditing and Taxation, 23(2), 74-86.

Baehaqi, A. (2014). Usulan model sistem 
pengawasan syariah pada perbankan syariah di Indonesia. Jurnal Dinamika Akuntansi dan Bisnis, 1(2), 119-133.

Bank Mandiri Syariah Annual Report for 2017, accessed on February 5, 2019.

Bukair, A. A., \& Rahman, A. A. (2015). The effect of the board of directors' characteristics on corporate social responsibility disclosure by Islamic banks. Journal of Management Research, 7(2), 506.

CISI. (2010). Islamic Finance Qualification. London UK.

Elad, F., Wong, M. N., \& Bongbee, N. (2018). The Role of board characteristics in effective corporate governance: The case of Airbus Group. International Journal of Social Sciences Perspectives, 2(1), 87-95.

Fahlevi, H., \& Randa, P. (2017). Financial performance and sharia compliance: a comparative analysis of Indonesian and Malaysian Islamic banks. Business dan Economics Review, 26(2), 41-52.

Ginena, K., \& Hamid, A. (2015). Foundations of Shari'ah governance of Islamic banks. United Kingdom: Wiley.

Grais, W., \& Pellegrini, M. (2006). Corporate governance in institutions offering Islamic financial services: issues and options. The World Bank.

Hasan, Z. B. (2009). Regulatory framework of Shari'ah governance system in Malaysia, GCC Countries and the UK. Kyoto Bulletin of Islamic Area Studies, 3-2.

Hasan, Z. (2014). In search of the perceptions of the Shari'ah scholars on Shari'ah governance system. International journal of Islamic and Middle Eastern finance and management. $7(1), 22-36$.

Haridan, N. M., Hassan, A. F., \& Karbhari, Y. (2018). Governance, religious assurance and Islamic banks: Do Shariah boards effectively serve?. Journal of Management and Governance, 22(4), 1015-1043.

Ibrahim, S. H. M., Wirman, A., Alrazi, B., Nor, M. N. B. M., \& Pramono, S. (2004, April).
Alternative disclosure and performance measures for Islamic Banks. In Second Conference on Administrative Sciences: Meeting the Challenges of the Globalization Age, King Fahd University of Petroleum \& Minerals, Dhahran, Saudi Arabia (pp. 1921).

ISRA. (2015). Sistem Keuangan Islam Prinsip dan Operasi. Jakarta: PT. Raja Grafindo Persada.

Khalid, A. A., Haron, H. H., \& Masron, T. A. (2017). Relationship between internal Shariah audit characteristics and its effectiveness. Humanomics.

Noordin, N. H., \& Kassim, S. (2016). Does Shariah committee composition influence Shariah governance disclosure? evidence from Malaysian Islamic banks. Journal of Islamic Accounting and Business Research, 10(2), 158-184.

Nugraheni, P. (2012). Kebutuhan dan Tantangan Audit Syariah dan Auditor Syariah. Jurnal Ekonomi \& Keuangan Islam, 2(1), 76-88.

Peraturan Bank Indonesia (PBI) No.11/33/PBI/ 2009 tentang Pelaksanaan Good Corporate Governance (GCG) Bagi Bank Umum Syariah (BUS) dan Unit Usaha Syariah (UUS).

Peraturan Bank Indonesia (PBI) No.13/2/PBI/ 2011 tentang Pelaksanaan Fungsi Kepatuhan Bank Umum.

Prakosa, N. I., \& Zuchri, L. (2011). Menggagas Konsep Penerapan Shariah Compliance Audit: Sebuah Upaya Pencapaian Islamic Corporate Governance. Jurnal Ekonomi \& Keuangan Islam, 1(1), 79-87.

Rahman, A. A., \& Bukair, A. A. (2013). The influence of the Shariah supervision board on corporate social responsibility disclosure by Islamic banks of Gulf Co-operation Council countries. AJBA, 6(2).

Surat Edaran Bank Indonesia (SEBI) No.12/13/DPbS/2010 tentang Pelaksanaan GCG Bagi BUS dan UUS

Segarawasesa. Fajar. (2018). Determinan Tingkat Kepatuhan Syariah Pada Bank 
Syariah di Indonesia (Thesis, Universitas Islam Indonesia, Yogyakarta).

Shamsuddin, A., Manjiegar, D. B., \& Kirupanangtan, K. (2014). Factors that determine the effectiveness of internal audit functions in the malaysian public sectors. International Journal of Business, Economics and Law, 5(1), 9-17.

Violita, E. S., \& Handarbeni, G. (2017). Analisis Efektivitas Dan Tinjauan Audit Syariah Dalam Pelaksanaan Dan Pengawasan
Kepatuhan Syariah Pada Bank Syariah. JRB-Jurnal Riset Bisnis, 1(1), 41-50.

Yahya, Y., \& Mahzan, N. M. (2012). The role of internal auditing in ensuring governance in Islamic financial institution (IFI).

Zainuldin, M. H., Lui, T. K., \& Yii, K. J. (2018). Principal-agent relationship issues in Islamic banks: a view of Islamic ethical system. International Journal of Islamic and Middle Eastern Finance and Management. 